\title{
Four Kingdoms Will Rule: Echoes of Apocalypticism and Political Reality in Late Antiquity and Medieval Judaism
}

\author{
Wout Jac. van Bekkum
}

\section{Historical Allusions?}

The second chapter of the book of Daniel, verses $31-45$, records the account of king Nebuchadnesar's dream, in which he saw "... an enormous, dazzling statue, awesome in appearance. The head of the statue was made of pure gold, its chest and arms of silver, its belly and thighs of bronze, its legs of iron, its feet partly of iron and partly of baked clay". Daniel's interpretation of the dream leads to a scheme of four successive kingdoms: "... After you, another kingdom will rise ... Next, a third kingdom ... Finally, there will be a fourth kingdom ... a divided kingdom ... partly strong and partly brittle ... the God of heaven will set up a kingdom that will never be destroyed, nor will it be left to another people..." The arrival of a fifth kingdom, the eternal reign of God, is represented by the collapse of the image, struck on its feet by a stone cut without hands. The image is shattered, while the stone grows and becomes a great mountain that fills the earth.

The seventh chapter, verses $1-28$, describes a vision or rather an apocalypse: "... Four great beasts, each different from the others, came up out of the sea. The first was like a lion, and it had the wings of an eagle ... a second beast, which looked like a bear ... another beast, one that looked like a leopard, and on its back it had four wings ... a fourth beast, terrifying and frightening and very powerful. It had large iron teeth ... and it had ten horns ..." Again, it is declared in Daniel that the beasts represent four kingdoms: "The four great beasts are four kingdoms ... but the saints of the Most High will receive the kingdom and will possess it for ever ... The fourth beast is a fourth kingdom that will appear on the earth. It will be different from the other kingdoms and will devour the whole earth ... The ten horns are ten kings who will come from this kingdom. After them another king will arise ... he will subdue three kings ..."

Daniel beholds these beasts coming up out of the sea, of which the fourth is a nameless monster with ten horns, amongst which springs up an eleventh that has eyes and a mouth speaking great things. The ten horns are also a reference to 
ten kings, while the eleventh horn is a king who shall make war with the saints of the Most High (qaddishey 'elyonin), and speak insolently against them. In this vision the climax is reached in the setting up of a throne, on which an Ancient of Days ('Atiq Yomin, Atiq Yomaya) sits in judgment, with the consequence of the destruction of the fourth beast, while the others have their lives temporarily spared, though they are shorn of their dominion. A (ke-)Bar Enash or (One like a) Son of Man then comes in clouds of heaven and receives everlasting dominion. The saints of the Most High eventually receive royal power in an empire that shall endure for ever.

A full analysis of these complex texts is beyond the scope of this article, but regardless of the many issues surrounding the Daniel apocalypses, most conspicuous is the theme of a succession of four kingdoms. Josephus in his Antiquities expresses the highest regard for Daniel and calls him 'a prophet of good tidings'. His interpretation of Daniel 2 is quite similar to that in the midrashic version of Exodus Rabba 35,5 ("Gold refers to Babylon; silver refers to Media; brass refers to Greece; Rome, that destroyed the Temple, is likened to iron"), however, he wished to avoid problems with his Roman readers and neglected potentially offensive details about the Roman Empire. ${ }^{1}$ The accounts of Daniel 2 and 7 are based on the number four. A four-part history and timetable is not exclusively apparent in the book of Daniel and its interpretations, but also in I Enoch 89-90, preceded by the Animal Apocalypse, and interpreted as the time of Babylonian captivity and Persian, Alexandrian, and Seleucid rule. ${ }^{2}$ A large quantity of commentators has disputed

1 With gratefulness to Prof. Dr. Günter Stemberger, University of Vienna, for his bibliographical advices. G. Vermes, "Treatment of the Book of Daniel”, Journal of Jewish Studies 42, 1999, pp. 149-166; J.C. VanderKam and W. Adler, The Jewish Apocalyptic Heritage in Early Christianity, Assen-Philadelphia: Van Gorcum Press 1996, pp. 212213.

2 Persian and Greek sources also mention four types of metals to convey their understanding of history by means of the number four; G.F. Hasel, "The Four World Empires of Daniel 2 against its Near Eastern Environment", Journal for the Study of the Old Testament 12, 1979, pp. 17-30. P. 18-23: Akkadian apocalypses contain the scheme of the rise and fall of empires. The Roman author Aemilius Sura writes in his book on the chronology of Rome (189-171 BCE): The Assyrians were the first of all the races to hold power, then the Medes, after them the Persians, and then the Macedonians. Then, when the two kings, Philip and Antiochus, of Macedonian origin, had been completely conquered, soon after the overthrow of Carthage, the supreme command passed to the Roman people. Between this time and the beginning of the reign of Ninus, king of the Assyrians, who was the first to hold power, lies an interval of 1,995 years ... The Greek poet Hesiod composed in the eighth century BCE his famous work Works and Days. He speaks of four (or five) ages, genoi, of men which are associated with four metals: gold, silver, bronze, iron ... Our investigation has indicated that the scheme of the four world empires in Dan. 2 can no longer be supposed to be the result of a unilinear development from either Greek and/or Persian sources ... a possibly common 
the two chapters, addressing the question if and how the two episodes are linked together. Are the four monarchies of Daniel 2 and 7 identical or not? To what extent is the symbolism of the four-part image and the four beasts alluding to the same schema? What is actual and what is mythological about it? Is Bar Enash or are the most high saints messianic figures, if so, what is Danielic Messianism? The main question of all is self-evidently the identification of the four kingdoms: Daniel 2 is often understood as four representative successive kings within the Neo-Babylonian kingdom, for instance, Nebuchadnesar as gold, Evil-Merodach as silver, Neriglissar, Labashi-marduk or Laborosoarchod as bronze, with Nabonidus as the mingled iron and clay. A more conventional interpretation of Daniel 2 is: the Chaldean kingdom of Nebuchadnesar, the Median kingdom of Darius, the Persian kingdom of Cyrus, and the Greek kingdom of Alexander, and that of Alexander's successors. Others choose for a general course in supposing that Daniel 2 refers to the Chaldeo-Medo-Persian empire, the Greek, the Roman, and the divided states of Europe from the fifth century onwards. Daniel 7 is equally understood as the Babylonian empire of Nebuchadnesar, the Persian empire of Cyrus, the Greek empire of Alexander, and the empire of Alexander's successors. ${ }^{3}$ Others hold the four kingdoms to be Babylonian, Median, Persian, and Greek. Some later authors propose a rather symbolic identification like false religion, idolatry, Islam and Deism. Late Greek and Roman sources are aware of the list of five monarchies including Rome as the fifth one, but most Christian exegetes include Rome according to the Danielic idea as the fourth empire. ${ }^{4}$

prototype of a scheme of four successive kingdoms, dynasties, or empires; S.B. Reid, Enoch and Daniel, A Form Critical and Sociological Study of the Historical Apocalypses, BIBAL Monograph Series 2, North Richland Hills, Texas: BIBAL Press 2004; P.A. Tiller, A Commentary on the Animal Apocalypse of I Enoch, Atlanta, Georgia: Scholars Press, 1993, p. 226: Sethites are represented by white cattle but Cainites by black cattle. Israel is represented by white sheep; Esau and Edomites by black boars; p. 274: A wild ass, this is Ishmael; p. 354: The use of horns is to represent political leaders.

3 H.H. Rowley, Darius the Mede and the Four World Empires in the Book of Daniel, A Historical Study of Contemporary Theories, Cardiff: University of Wales Press Board, 1935, pp. 61-173: The Four World Empires (pp. 61-66: Introduction; pp. 67-69: The First Kingdom is the Neo-Babylonian; pp. 70-137: The Fourth Kingdom is the Greek; pp. 138-160: The Second and Third Kingdoms are the Persian and the Median respectively; pp. 161-173: The interpretations that find Four Kings, instead of Kingdoms, are unsatisfactory).

4 Augustine's interpretation that the Kingdom of God will not come on earth and that the corporeal bodies will dwell in heaven, is strongly linked to the millenarian scheme of six world ages and the seventh eschatological age of the great Sabbath (Apocalypse, ch. 20); J.J. Collins, "Jewish Apocalyptic against its Hellenistic Near Eastern Environment", BASOR 220, 1975, pp. 27-36. 
Judaism

It is with regard to this latter so-called Roman View that discussion of the four empires in Judaism bears great significance for a standardised worldview, shaped by two aspects: political reality and eschatological outlook. ${ }^{5}$ Jewish judgment of the growth of Roman political power in the classical age, and religious Christian power in Late Antiquity, was generally based on the same traditional terminology with already then a long history in biblical and rabbinical exegesis. For that matter, the theme of the four empires can easily be included whenever there is a reason to establish an explanation upon the number four. ${ }^{6}$

Most concepts originate in the Hellenistic period and are closely connected with one more or less generally accepted interpretation of Daniel 7 (with the exception of Qumranic texts), according to which the apocalyptic vision of world history or supra-history is revealed. ${ }^{7}$ Jewish sages adhered to the vision of

5 A Qumranic precedent for the identification of the four kingdoms and the changing thereof, cf. J.J. Collins, "Apocalypticism and Literary Genre", The Dead Sea Scrolls after Fifty Years II, Leiden 1999, pp. 415-417; M. Hadas-Lebel, Jérusalem contre Rome, Paris: Les Éditions du Cerf, 1990, pp. 453-488: Du Refus de l'Apocalypse à l'Apocalypse éclatée; p. 460: Rome - Ésaü - Édom; p. 461: Les frères ennemis; p. 473: Rome "quatrième empire"; p. 476: Le symbolisme animal; p. 478: La valeur eschatologique du symbole du porc.

6 The number four plays a crucial role in rabbinic exposition, not just in a four-part structure of motifs in midrashim but also in the quality of a rhetorical pattern repeating and comparing words and ideas in parallellisms and paradoxes. As has been suggested by Aharon Mirsky in his ground-breaking article Mahtzavtan shel Tzurot ha-Piyyut (Studies of the Research Institute for Hebrew Poetry VII, Jerusalem 1958 pp. 3-129), a four-part model derived from the principles of logic by which the Bible may be expounded, the middot, has been of great influence upon Hebrew liturgy and poetry. Within the lines of early 'avodot by Yossi ben Yossi, a sophisticated fourfold pattern of lines is apparent. In the verses of classical, Byzantine-Jewish hymnists like Yannai, Yehudah, and Qilir, basic prosodic features are a quatrain of versets and rhyming quatrains or strophes, the dominant model for mediaeval Jewish hymnists throughout the Mediterranean world and in central and eastern Europe.

7 C.C. Caragounis, "History and Supra-History: Daniel and the Four Empires", in: A.S. van der Woude (ed.), The Book of Daniel in the Light of New Findings, Leuven: Uitgeverij Peeters/Leuven University Press, 1993, pp. 387-397: Caragounis calls the book of Daniel 'a highly symbolical book not merely concerned with history, but with supra-history where historical events are interpreted not only from a Jewish point of view but also in a dynamic way. Identification of the four empires should be made on the basis of clues given by the book itself, the actual course of history and the author's dynamic interpretation of that history'; p. 389: My thesis is that the concerns of Daniel point to the identification of the fourth empire with that of Greece, that the author's identification of the second beast with Media is in complete accord with history, and that the four beasts / empires and especially the fourth one must be interpreted in the light of other-worldly categories'; E.C. Lucas, "The origin of Daniel's four empires scheme reexamined”, Tyndale Bulletin 40,2, 1989, pp. 185-202. 
the four great beasts as an outline for the actual history of four successive empires: Babylon, Persia, Greece and Rome. Ultimately, the Roman Empire would be overthrown and a messianic king would establish the hegemony of Israel. The latter eschatological conception is often exemplified by the account of Gen. 25:23: "Two nations are in your womb, and two peoples from within you will be separated; one people will be stronger than the other, and the older will serve the younger." The twin brothers Esau and Jacob represent the two peoples of Rome/Byzantium and Israel, and the typology of Rome in the biblical image of Esau-Edom as an obverse of Jacob-Israel enabled the sages to apply the traditional world-view to their own situation. ${ }^{8}$

In Midrash Genesis Rabbah 16,4 the four rivers separated from a river flowing from Eden (Gen. 2:10-14) are connected with the four kingdoms using the etymology of their names for a qualification of each kingdom:

A river watering the garden flowed from Eden. Said R. Menahma or R. Tanhuma: The Holy One, blessed be He, will make the peoples of the world drink a cup of bitterness from the place whence this river issues. What is the proof? A river flowed, this alludes to the four kingdoms corresponding to the four heads into which it was divided. The name of the first is the Pishon: this is Babylon, so called with reference to the verse: And their horsemen spread themselves (pashu, Hab. 1:8) ... And the name of the second river is the Gihon: this alludes to Media ... in allusion to the verse: You will crawl on your belly (gehonkha, Gen. 3:14) ... And the name of the third river is the Hidekel (the Tigris): this alludes to Greece, which was sharp ( $h a d$ ) and swift ( $k a l)$ in its evil decrees, for she ordered Israel: write upon the horn of an ox that you have no portion in the God of Israel ... And the fourth river is Perath (the Euphrates): that is Edom, Perath denoting that it upset (hefirah) and harassed His world, Perath denoting that it was fruitful (parath) and increased through the blessing of that old man (Isaac), Perath denoting that I (God) will ultimately consign it to oblivion (hafer), Perath on account of its ultimate destiny, as it is written: I have trodden the winepress (purah) alone (Is. 63:3).

In the same midrashic collection 44,17 a verse like Gen. 15:12 ("A thick and dreadful darkness came over him") is employed for the four-part division of world history (Genesis Rabbah 44,17). A striking fact is that this biblical verse is interpreted twice in a reversed order of allusions:

Dreadful refers to Babylon ... darkness refers to Media ... thick refers to Greece ... came over him alludes to Edom (Rome) ... Some reverse it: Came over him alludes to Babylon ... thick alludes to Media ... darkness alludes to Greece ... dreadful alludes to Edom (with reference to Daniel 7:7: There was a fourth beast, dreadful).

8 J. Maier, "Israel und 'Edom' in den Ausdeutungen zu Dt 2,1-8”, in: G. Stemberger, C. Thoma, J. Maier, Judentum - Ausblicke und Einsichten, Festschrift für K. Schubert zum 70. Geburtstag, Frankfurt/M: Lang 1993, pp. 135-184, reprint in: J. Maier, Studien zur jüdischen Bibel und ihrer Geschichte, Berlin/New York: Walter de Gruyter 2004, pp. 285325; L. DiTomasso, The Book of Daniel and the Apocryphal Daniel Literature, LeidenBoston: Brill, 2005, pp. 39-75, 104-107. 
Such and many other traditions may exhibit what the theme of the four kingdoms came to mean in Judaism during the Graeco-Roman period. Discussion and exposition of this order are also represented in medieval commentaries, where it is explicitly stated that the four kingdoms are considered as instrumental during the long period of Israel's exile and subjugation. ${ }^{9}$ As can be frequently found in midrashic and talmudic exposition, the four kingdoms turn into a divine tool for the sake of chastising and punishing the people of Israel, whereupon the four empires in their turn will be overthrown and punished for their evil acts. Here can be noticed that this mode of interpretation is closely bound to a prominent example from the book of Exodus: the power and the glory of Egypt and its divine king, the Pharaoh, are often considered as instrumental in the redemption history of the slave people of Israel. This is one of the reasons why in the Jerusalem Talmud, compiled during the fourth and fifth centuries in Palestine, the ritual of drinking four cups of wine during the first eve of Passover is associated with the four kingdoms as a symbol of retribution and redemption. In Genesis Rabbah 44,5 Egypt and the four kingdoms appear in one expression ("Egypt and the four empires will subject you to slavery"), turning the theme into a trial of faith. Foreign rule is God's severe test of Israel, moving the people to the verge of despair. Another interesting association is being made with the patriarch Abraham who according to Gen. 14:9 made war with the four early kings of Elam, Goiim, Shinar and Ellasar. In some expositions (Genesis Rabbah $42,2)$ they are adduced as an early parallel to the four kingdoms of Babylon, Media, Greece and Edom/Rome. In a similar tradition (Genesis Rabbah 58,4) these early kings are designed as kosmokratorin, cosmocrats, a common title of the Roman-Byzantine emperor, and therefore identified as the representatives of the four world empires. Such traditions seem to emphasize the immediacy of God's presence in the world and His direct relation to world history, in contrast to other accounts which are more based on the theological perspective of Israel's role in the world and God's purpose for all mankind.

\section{Political Reality}

So far it is evident that rabbinic literature provides the universal and dramatic scope for a Jewish approach of the actual situation which deteriorated rapidly after the establishment of Christian political and religious rule in East and West. An outstanding example of this development for the worse is a letter concerning the date of the Easter festival which the emperor Constantine sent to all provinces after the Council of Nicaea in 325. In this document the Jews were

9 The $11^{\text {th }}$-century-commentator Rashi on Gen. 15:14: "It is a reference to the sufferances and darkness of the periods of exile". 
called 'murderers of prophets' and 'God-killers'. Protection was granted to Jews who wished to abandon their religion, and gentiles were warned not to join the so-called 'nefarious sect'. Christians should not celebrate Easter in any relation to the date of the Jewish Passover festival, because, according to the contents of the letter 'Jews have stained their hands by a serious crime and defiled their souls as a result of their cruel conduct.' The actions of Constantine and his family promoting Christianity seem to have evoked Jewish reactions of a messianic nature. The so-called 'small apocalypse' in the rabbinic codex of the Mishnah (Sotah 9,15) is apparently connected to the early fourth century; this text is in any case dated before the reign of Julian the Apostate:

With the footprints of the Messiah presumption increases, and death increases. The vine gives its fruit and wine at great cost. The kingdom turns to heresy, and there is no reproof. The gathering place will be for prostitution, Galilee will be laid waste, the Golan will be made desolate, and the men of the frontier will go about from town to town, and none will take pity on them. The wisdom of scribes will putrefy, those who fear sin will be rejected. The truth will be locked away. Children will shame elders, and elders will stand up before children: for the son dishonors the father and the daughter rises up against her mother, the daughter-in-law against her mother-in-law; a man's enemies are the men of his own house (Micah 7:6). The face of the generation is the face of a dog, a son is not ashamed before his father. Upon whom shall we depend? Upon our Father in heaven!

Judaism as a power of some societal importance came to an end, and towards the late fourth and fifth centuries the political role and legal status of Jews was gradually limited by the enactment of a number of laws given by Theodosius I. The law of the year 384 was addressed to the Jews and forbade them (again) to buy Christian slaves and to disgrace them by the Jewish sacrament, that is, by circumcision. The law of 388 repeated previous prohibitions of mixed marriage with the addition that a mixed marriage was now considered as adultery for which the death penalty was introduced. These and similar laws of Theodosius I cannot be considered as a final blow to Judaism, on the contrary, warnings were included to some regional and local authorities who prohibited Jews to convene in their synagogues and destroyed the buildings. The situation under Flavius Theodosius Junior or Theodosius II was much more insecure: most peculiar is one of his first imperial decrees of 29 May 408 (CTh 16, 8, 18), prohibiting the celebration of the feast of Purim because of the accusation that the Jews equated the evil Haman the Amalekite in the book of Esther with Jesus Christ:

The governors of the provinces shall prohibit the Jews, in a certain ceremony of their festival Haman in commemoration of some former punishment, from setting fire to and burning a simulated appearance of the holy cross, in contempt of the Christian faith and with sacrilegious mind, lest they associate the sign of our faith with their jests. They shall maintain their own rites without contempt of the Christian law, and they shall unquestionably lose all privileges that have been permitted heretofore unless they refrain from unlawful acts. 
Most likely the custom of burning a crucified doll-like effigy of Haman was widespread among the Jewish communities on the day of Purim. The custom was interpreted by Christians as an actual murder rather than only a symbolic one. The Book of Esther speaks explicitly of 'the hanging of Haman' (Esther 9:10), but other sources apparently mention 'the crucifixion of Haman.' The compilation of contemporary expositions on the Book of Esther, assembled in Midrash Esther Rabbah, seems to be the most elaborate when it concerns the four kingdoms. The proöimia to this midrashic work reflect traditions from around the year 500, when there was sufficient reason to include the four empires in the following manner, opening with Deut. 28:67: "In the morning you will say: If only it were evening, and in the evening: If only it were morning - because of the terror that will fill your hearts and the sights that your eyes will see":

In the morning of Babylon you will say: If only it were evening [when Babylonian power is at its height you will hope for the commencement of the next ruling kingdom, so that it might free you from Babylonian oppression]. In the morning of Media, Greece and Edom/Rome you will say: If only it were evening ... Yet in spite of this, when they are in the land of their enemies, I will not reject them or abhor them so as to destroy them completely, breaking my covenant with them. I am the Lord their God (Lev. 26:44). We can easily understand why Samuel [the sage] explained: I did not reject them, in Babylonia, I did not abhor them, in Media, to destroy them completely, when subject to Greece, breaking My covenant with them, when subject to the empire of evil. I am the Lord their God, in the messianic era. Rabbi Hiyya taught in addition: I did not reject them, in the days of Vespasian, I did not abhor them, in the days of Trajan, to destroy them completely, in the days of Haman [Hadrian], breaking my covenant with them, in the days of the Romans. I am the Lord their God, in the days of Gog and Magog.

The Esther proöimia repeatedly return to the major theme of the four kingdoms, comparing them to animals: lion, bear, leopard, serpent, sometimes even with a positive undertone when Greece is likened to a dove: The dove refers to Greece because throughout the days of the Greek domination the Temple was standing and Israel used to offer pigeons and doves on the altar. The book of Esther and therefore the feast of Purim was a major reason to engage in religious debates of a (contemporary) political nature, even to the level of historical literal exegesis: The biblical text sometimes mentions Persia before Media and sometimes Media before Persia. When the sovereignty was from Persia, Media was secondary. When the sovereignty was from Media, Persia was secondary. Why is it called Persia? Because it obtained sovereignty in segments (Hebr. prusot) ... Why is it called Media? Because it bows (Aram. modya) to the will of the Holy One, blessed be He. A curious addition was made by Rabbi Hiyya bar Abba: The kings of Media were blameless, and God had no complaints against them save on the ground of their idolatry, which was transmitted to them from their ancestors. The kings of Media are excused! 


\section{The Seventh Century}

The year 614 started with high expectations when the Persians under the command of general Shahrbaraz invaded Palestine and rushed from Damascus through Tiberias, Sepphoris, Caesarea, and Lydda. The conquest of Jerusalem was within reach; in Jewish eyes the events were interpreted as a reenactment of the conquest in $538 \mathrm{BCE}$ according to the books of Nehemiah and Ezra, when the Persian king Cyrus allowed the Judeans to return to the city and to rebuild the walls, the houses, and the Temple. The large Jewish communities in the southern part of the Lebanon and northern Palestine joined the Persians in a triumphal march to Jerusalem. The Christians of the city surrendered to Shahrbaraz, but in the spring of 614, after he marched to Egypt, they expelled his garrison. Shahrbaraz turned back, besieged and captured Jerusalem, and deported most of its Christian population to Persia. Many churches were demolished and the supposed True Cross of Christ was removed from the Church of the Holy Sepulchre. ${ }^{10}$

Unfortunately, the information about this period when Jerusalem was supposedly more or less in Jewish hands under the aegis of Persia between the years 614 and 617 is very meagre, but one may assume that the perception of this historical event and its reverberations in the imagination of the contemporaries caused an intensification of messianic and apocalyptic thought. ${ }^{11}$ This type of apocalypticism is greatly influenced by popular Jewish eschatology, which emphasized the historical struggle between Israel and the nations within the Edom-Israel scheme. An inquiry into the actual history of the

10 J. Starr, "Byzantine Jewry on the Eve of the Arab Conquest (565-638)", Journal of the Palestine Oriental Society 15, 1935, pp. 280-293; A. Sharf, "Byzantine Jewry in the Seventh Century”, Byzantinische Zeitschrift 48, 1955, pp. 103-115; A. Palmer, The Seventh Century, p. 128; W. Treadgold, A History of the Byzantine State and Society, p. 292.

11 G. Dragon - V. Déroche, "Juifs et chrétiens dans l'Orient, Introduction historique", Travaux et Mémoires XI, 1991, pp. 17-273; B. Flusin, Saint Anastase le Perse et l'histoire de la Palestine au début du VIIe siècle, 2 vols., Paris 1992; D.S. Russell, The Method and Message of Jewish Apocalyptic, London: SCM Press, 1964, pp. 285-286: The idea of the kingdom; pp. 286-290: The kingdom on this earth; pp. 290-291: The kingdom in heaven; pp. 291-297: A temporary kingdom followed by 'the age to come'; p. 285: The expression 'the kingdom of God' or 'the kingdom of heaven', so common in the New Testament, is not to be found anywhere in the Old Testament or in the apocalyptic writings. Nevertheless, the idea of the kingdom, in which the sovereignty of God is yet to be revealed, is basic to the teaching of both bodies of literature ... Gentile kingdoms seemed so overwhelming and terrible ... establishment of the kingdom of God ... offers a solution to the mystery of God's dealings with His people Israel; p. 286: The Book of Daniel; R.K. Emmerson and B. McGinn, The Apocalypse in the Middle Ages, Ithaca and London: Cornell University Press, 1992; G.J. Reinink, Syriac Christianity under Late Sasanian and Early Islamic Rule, Hampshire: Ashgate/Variorum 2005. 
time offers hardly any certainty about the synthesis of a rebellious attitude of Jews towards the Byzantines and the rise of interest in apocalyptic and messianic ideas. It remains to be seen to what extent the traumatic-historic interpretation of the Danielic scheme can be applied to the literature related to the days of Heraclius. One peculiar writing, Sefer Zerubbavel or the Book of Zerubbabel, offers a picture of the last days of the world with motifs that are known from biblical and rabbinic literature:

And the tenth king is Armilos, son of Satan, who came forth from the stone statue of a woman. Armilos will come with the kings of Qedem and start a war with the sons of Qedar in the valley of Arbael. ${ }^{12}$ The kingdom was theirs. He will ascend in his strength and has in mind to conquer the whole world. He will begin to plant on the face of the earth all the false gods of the nations, whom God hates. He will then take his mother, the stone from which he was born, out of the house of disgrace. Seven altars will be built for her; this will be the ultimate idolatry. From all over, the nations will come to worship that stone, burn incense, and pour libations to her. No one will be able to look upon her face because of her beauty. Whoever does not bow down to her will die, suffering like an animal. Armilos will anger God by his evil deeds.

The two messianic figures and an apparently earlier Armilos typology are also preserved in poetic form in a hymn of consolation for the Ninth of Av, the traditional Jewish date on which the destruction of the first and second Temple is commemorated. This anonymous hymn (supposedly ascribed to the famous hymnist El'azar Qilir or Kalir) is certainly closer in time to an original version of the Book of Zerubbabel: ${ }^{13}$

The king of the West and the king of the East, they will crush each other; and the king of the West: his armies will show strength in the country; and from Yoktan a king will go forth: his armies will be strengthened in the country Edomites and Ismaelites will fight in the valley of Acre, until their horses will sink in blood and panic ... and Harmalyos will come and he will stab the Messiah of God, the [other] Messiah will come and he will revive him by the word of God, and all Israel will have faith in him.

12 An elaboration of the motif of the ten kings can also be found in Pirke de-Rabbi Eliezer as well as in the Targum to Esther; U. Glessmer, "Die 'vier Reiche' aus Daniel in der targumischen Literatur", in: J.J. Collins and P.W. Flint (eds.), The Book of Daniel, Composition and Reception, Leiden: Brill, 2001, pp. 468-489.

13 J. Yahalom, "On the Validity of Literary Works as Historical Sources", Cathedra 11, 1979 , pp. $125-133$, esp. p. $130,1.6-8$, p. 131, 1. 22-23, p. 132, 1. 54-56; R. Hoyland, Seeing Islam as Others saw it, pp. 319-320: "On That Day"; J. Yahalom, "The Temple and the City in Liturgical Hebrew Poetry”, pp. 278-280. 
Apocalypticism in Liturgical Hymns

The eschatological content of this pseudo-Qiliri piyyut seems to reflect the cataclysmic events of the time and specifies by name the three nations which take part in the war: 'The king of the West' or 'the Edomites' (Byzantium), 'the king of the East' (Persia), and 'the king of Yoktan' or 'the Ishmaelites' (Arabia). Moreover, the poem could have been written in direct response to specific events after 617 when the Persians drew some political conclusions from the limited significance of their Jewish supporters and reinstalled the Christian Monophysite population of Jerusalem. All Jews were deported from the city. The sudden loss of Persian protection must unavoidably have been a tremendous disappointment for the Jews. Their disillusion must have been even greater when they were told that Heraclius astonishingly reoccupied almost all of the lost territories of the Byzantine Empire, culminating in the capture of Ctesiphon in 628. Ultimately he succeeded to return to Jerusalem with the relique of the True Cross in 630. Jews experienced terrible years of compulsory baptism, persecution and death decreed by Heraclius, which lasted until the Arab capture of Tiberias in 636 and Jerusalem in $637 .{ }^{14}$ In a second anonymous poetic fragment close to the first, visionary sections can be found which tie 'the commander-in-chief' (sar ha-rosh) or 'the capstone' (ha-'even haroshah) and Armilos together. Ezra Fleischer believes that 'the commander-in-chief' means the military leader of the Persians killing the Messiah son of Joseph in Jerusalem. ${ }^{15}$ This could be true, but it is quite certain that at a later date 'the commander-in-chief' or 'the capstone' were understood as Armilos within the context of the Zerubbabel traditions: ${ }^{16}$

The land is mourning all by itself, because the anointed of the war (the Messiah son of Joseph) is lost, the mourning for him will be very grievous, the enemy [and his army will be too strong for him], this is the capstone that will be placed, this is the little horn the pleasant man (Daniel) has visioned, who stood amidst ten horns, and three horns he intends to overthrow, the holy people will be destroyed (lehashmid, possibly: coerced into apostasy), persecution (shmad) is decreed upon them.

That is Armalyos, that is his name, [God] will cause him to crush and to tear down, He will appoint him to destroy (or: to coerce into apostasy) and to annihilate, and he will put down an idol for his [own] name, whoever does not kneel he will condemn him to death, whoever does not bow he will spill his blood, by means of [the idol] he will curse God and His people, he will oppress those who

14 According to the letter of Maximus Confessor to a certain Johannes Presbyteros (perhaps to be identified with John of Kyzikos) compulsory baptism for the Jews and expulsion from Jerusalem was decreed in 632. The historical consequences of this decree are described in the Doctrina Jacobi, ed. V. Déroche.

15 E. Fleischer, "Solving the Qiliri Riddle", Tarbiz 54, 1985, pp. 383-427, esp. p. 404, n. 59: Fleischer erroneously took two apocalyptic piyyutim as one whole.

16 E. Fleischer, "Solving the Qiliri Riddle", pp. 414-415. 
God has carried since their birth (Israel), he will trample and tread on His whole footstool (the entire world).

There is no clear evidence, but with all cautious assessment this apocalyptic description of Armilos could reflect a contemporary dislike of Heraclius' antiJewish policies and his special efforts to reconstruct the ruined holy sites of Christendom in Jerusalem. Heraclius' hostility to Jews and its religious implications in that particular period of time has extensively been demonstrated in Byzantine literature, as can be exemplified by the court historian Theophylact Simocatta who writes in his Historiae: "The Jews are a wicked and most untrustworthy race, trouble-loving and tyrannical, utterly forgetful of friendship, jealous and envious, and most implacable in emnity." ${ }^{\prime 7}$ The apocalyptic hymnic references to Armilos are difficult to substantiate on the historical level but the intensity of concern toward this type of an anti-Messiah could well be explained as a reaction to Heraclius' military and religious activities in the region. ${ }^{18}$ These hymns were copied over and again in the course of centuries without emendation or omission, and it is for this reason that liturgical poetry of apocalyptic nature has come down to us as a source of information, whatever its limitations as a historical account may be.

\section{The Four Monarchies Reconsidered}

It is, however, essential to pay attention to a specific moment in historical time, in order to better understand an eschatological event. The complicated transition from Persian and Christian rule to the dominance of Islam triggered new expectations and asked for a reconsideration of the Danielic scheme of the four kingdoms. ${ }^{19}$

17 M. Whitby, The Emperor Maurice and his Historian Theopylact Simocatta on Persian and Balkan Warfare, Oxford 1988, p. 335; W. Kaegi, Byzantium and the early Muslim conquests, pp. 116-117: Heraclius had ordered a massacre of Jews around Jerusalem and in the mountains of Galilee, presumably in 630. Many Jews had fled from this action. This massacre surely embittered Jewish survivors, who would have looked even more favorably on the Muslims. The fact of a massacre is credible, but the actual number of Jewish victims is unknown, as is the nature and distribution of the surviving Jewish communities.

18 The fictional Armilos and his identification with the historical ruler Heraclius shows characteristics similar to the tendency in Christian apocalypticism to connect a personal ruler with the Last Emperor, cf. P.J. Alexander, The Byzantine Apocalyptic Tradition, Berkeley 1985, pp. 174-184; cf. also M. Idel, Messianic Mystics, New Haven \& London 1998, pp. 273-279.

19 R. Hoyland, Seeing Islam as Others saw it, pp. 527, 532-535; on the attitude of the Jewish communities of Babylonia and Persia to the Muslim conquest, cf. M. Gil, "The Babylonian Encounter and the Exilarchic House in the Light of Cairo Geniza 
Like Qilir or Kalir, other synagogue hymnists or composers of poems for contemporary liturgy were involved in religiously inspired political observations according to the biblical scheme. The seventh-century hymnist Yohanan the priest is quite specific in his reference to the coming to power by the Arabs. $\mathrm{He}$ views the newcomers as fitting into a divine plan to wipe out the Byzantine Empire and therefore he versifies: ${ }^{20}$

Disposses the mountain of Seir and Edom, speak to Ashur: he has to make haste and hurry, to plough down a godless nation by your mighty sceptre, to tread them down by the kingdom of the wild ass.

The name 'Assur' refers to the Arab conquerors (Hosea 8:9: "They have gone up to Assyria like a wild ass wandering alone") and not to the Persians. ${ }^{21}$ It is clear that the Arabs were expected to play a significant role in the messianicapocalyptic drama. Both Yohanan ha-Kohen and (pseudo-)Qilir tried to find confirmation for a new conclusion from the Hebrew Bible that the Ishmaelites or Kedarites were sent by God in order to deliver Israel from the Edomites. The recognition that Judaism and Islam had much in common may have stimulated the hope that the mission of the Arabs or the mission of Islam was to put an end to Christian beliefs and practices in the land of Palestine, to relax Heraclius' ban on Jewish access to Jerusalem, to expel his armies and to restore to the Jews their ancient rights. The high spirits of the moment are expressed in a belief in acute messianic redemption and salvation for Israel through Muslim triumph. The proliferation of apocalyptic verse was of great importance for Jewish selfdefinition and survival. With the aid of Psalm 83:7 (Edom and Ishmael are mentioned together in the phrase "The tents of Edom and the Ishmaelites") the centuries-old scheme of the four kingdoms was adapted to the permanence of Arab rule and Muslim domination. It was more preferable to envisage a new scenario for world history that assigned to the kingdoms a double name representing two successive powers. ${ }^{22}$ The discovery of an anonymous hymn

Documents and Parallel Arab Sources", Judaeo-Arabic Studies, Proceedings of the Founding Conference of the Society for Judaeo-Arabic Studies, edited by Norman Golb, Studies in Muslim-Jewish Relations 3, Amsterdam 1997, pp. 135-173.

20 N. Weisenstern, The Piyyutim of Yohanan ha-Kohen birabbi Yehoshua', Jerusalem 1984 (thesis), p. 78; J. Yahalom, "The Transition of Kingdoms in Eretz Israel (Palestine) as Conceived by Poets and Homilists", Shalem 6, 1992, pp. 1-22, esp. p. 6-7; W.J. van Bekkum, "Anti-Christian Polemics in the Piyyut", Early Christian Poetry, A Collection of Essays, Leiden 1993, pp. 297-308, esp. p. 307; on historiography in early Islam: F.M. Donner, Narratives of Islamic Origins, The Beginnings of Islamic Historical Writing, Princeton 1998, esp. pp. 275-296.

21 Pace E. Fleischer, "An ancient Jewish Tradition on the Date of the End of Byzantine Rule in Palestine", Zion 36, 1971, pp. 110-115; for pro-Muslim reactions in the years 635638: Y. Friedman, The History of al-Tabari XII, The Battle of al-Qadisiyyah and the Conquest of Syria and Palestine, New York 1992.

22 J. Yahalom, "The Transition of Kingdoms", p. 9. 
from the eighth century shows that the composer was concerned with an actualisation of the four kingdoms and employed the Danielic vision of the statue with its legs of iron, its feet partly of iron and partly of baked clay (Daniel $2: 31-35) .{ }^{23}$ This apocalyptic poem offers an estimate of the years of the rule of the fourth kingdom:

They will continue to rule for sixteen jubilee periods ( $16 \times 50=800$ years); starting with Edom and concluding with the Ishmaelites; the legs of iron include the Edomites;

and the feet of iron are the sons of Qedar (cunning as) foxes;

and the toes of the feet of iron are to be compared with the end of the kingdom (Dan 2:42);

and the toes of baked clay these are the Ashurim, the rod of the wicked and the sceptre of rulers (Dan 2:41; Is 14:5);

they keep the kingdom to the servant of rulers (Is 49:7). ${ }^{24}$

23 D. Flusser, "The four empires in the Fourth Sibyl and in the book of Daniel", Israel Oriental Studies II, Tel Aviv: Tel Aviv University, 1972, pp. 148-175. P. 153: The prophecy of four empires in the fourth Sibylline book is a witness for Oriental opposition to Hellenic imperialism; p. 159: The theory of five monarchies, with Rome as the fifth empire, is originally Roman or pro-Roman and it came into existence when Rome was added to the Eastern scheme of four empires; p. 161: Panathenaic Discourse of Aelius Aristides, who lived in the second century CE ... the famous orator knew the list of five empires: Assyria, Media, Persia, Macedonia, and Rome; p. 165: These are the four metals of the four ages of Hesiod (and Ovid). But the fourth kingdom is symbolized both by iron and by iron mixed with clay ... this irregularity was not caused by the special character of the fourth, Macedonian kingdom, as we could imagine from Daniel's explanation $(2: 40-43)$, but by his Persian source ... It is evidently not accidental that the periodisation in gold, silver, copper and iron is in its last two stages identical with the modern division of prehistory; p. 173-174: When the Jews later identified the fourth monarchy in Daniel with the Roman Empire, the whole idea of the four monarchies could continue to serve both Jews and Christians in their religious struggle against Rome. The vitality of the concept of the four empires can be demonstrated by the fact that when Rome is described as the last wicked power, she is always the fourth and never the fifth empire. The scheme of five empires, used in late Greek and Roman literature, is never anti-Roman (with one exception in VIII Sib. 6-11). The historical concept was created under Roman rule when Rome was added to the existing list by people who did not notice the anti-Western tendency of the older scheme.

24 It has been suggested in recent research that the detailed concentration on the toes of the statue suggests a further specialisation between Umayyad and Abbasid rule: 'the servant of rulers' or 'eved moshlim can be taken as 'Abd Muslim, the name of the reformer AbdalRahman Abu Muslim who brought the Abbasids to power in 754-755: B. Lewis, "An Apocalyptic Vision of Islamic History", BSOAS 13, 1950, pp. 308-338, reprint in Studies in Classical and Ottoman Islam ( $7^{\text {th }}-16^{\text {th }}$ Centuries), London 1976; J. Yahalom, "The Transition of Kingdoms", pp. 16-20. There are also striking parallels between the lines of this piyyut and a prosaic writing called The Secrets of Rabbi Simon bar Yohai. 
In the liturgical poems of Pinhas the Priest, who was active as a hymnist in the same period we find a startling harmonisation of the ancient motif and contemporary perception: ${ }^{25}$

You have torn apart the kingdom of Babylonia and Chaldea by strife,

You have moved away Media and Persia, Greece and Macedonia,

Qedar and Edom You will now set to destruction,

in sight of all You will raise Your voice unto us, O Lord.

Four prevailed against four in shrewdness

until iron was crushed into dust ...

Twice as strong was the Chaldean kingdom of the Chaldeans ...

Fifty-two [years] were assigned to the Medians ...

when the Persian kingdom was coupled to Media ...

One hundred eighty [years] Greece ruled ...

[Israel] was closed in ... Macedonian kingdom ...

Nine hundred eighty-six [years] was [Israel] dispersed in the kingdom of Edom, until You, radiant and ruddy lover [God], will grant justice to Your people ... Its respect was gone in making double the empire of the Ishmaelites,

until You will show compassion with Your people of children and infants ... Four hundred thirty-three [until] the end of clay in the world, until Your people will break the bars of their yoke.

When Pinhas inserts the topos of the four kingdoms into his verse, he consistently enumerates four pairs of kingdoms which makes them eight: Babylon and Chaldea, Persia and Media, Greece and Macedonia, Edom and Ishmael. The double number of empires enables the composer to include the Arab conquest of Palestine into the ancient historical scheme. Although he prays for the imminent redemption of Israel, both Roman and Arab or Christian and Muslim rule have to come to an end.

\section{Medieval Resonance}

An anonymous commentary on Joel 1:1-12 in connection with the symbols of the four kingdoms is found in the Genizah manuscripts collection of Oxford, Bodleian Library, Heb.d.56. ${ }^{26}$ This fragment consists of two parts: fol. 20a-21b and fol. 22a-23b. Both parts belong to a commentary on Joel 1, 1-12, according to a tripartite structure known from the Karaite commentary tradition: firstly, a verse-by-verse discussion and an explanation, secondly a literal translation into Judaeo-Arabic, thirdly a commentary in Judaeo-Arabic.

25 S. Elizur, The Liturgical Poems of Rabbi Pinhas ha-Kohen, Jerusalem 2004, pp. 210-212; p. 510.

26 M. Polliack and K. Shallem, "An Anonymous Genizah Commentary on Joel 1:1-12 and Biblical Symbols of the Four Kingdoms", Ginzei Qedem 1, 2005, pp. 171-243. 
The second bifolia contains a detailed exegesis of the first five verses. Despite the continuous numbering, fol. $22 \mathrm{a}$ is not a direct continuation of fol. $21 \mathrm{~b}$. Fol. 20a opens with the last lines of a commentary on Hosea, in Arabic: kamila sefer Hoshea bi-awni-llah nabtadi-l-aan bi-tafsir Yoel, that is, "The book of Hosea is completed with the aid of God; let us start with an explanation of Joel". The fragment therefore is part of a larger composition: a commentary on the books of the Twelve Minor Prophets.

The discussion of Joel 1:4 ("Tell it to your children, and let your children tell it to their children, and their children to the next generation: What the locust swarm has left the great locusts have eaten; what the great locusts have left the young locusts have eaten; what the young locusts have left other locusts have eaten") has prompted the anonymous commentator to leave the biblical order and to enter into an exposition of various symbols for the description of the four kingdoms, opening with the words: 'The four empires are designated by various terms'. The entire page is devoted to a comparison between the symbolical names from Daniel (the materials, the beasts) and Zechariah (as in Zech 6:1-8: "I looked up again - and there before me were four chariots coming out from between two mountains - mountains of bronze. The first chariot had red horses, the second black, the third white, and the fourth dappled [and] powerful. I asked the angel who was speaking to me, What are these, my lord? The angel answered me, These are the four winds of heaven (ruhot hashamayim) going out from standing in the presence of the Lord of the whole world. The one with the black horses is going towards the north country, the one with the white horses towards the west, and the one with the dappled horses towards the south. When the powerful [horses] went out, they were straining to go throughout the earth. And he said: Go throughout the earth. So they went throughout the earth. Then he called me and spoke: Look, those going towards the north country have given my spirit (ruhi) rest in the north country").

The Zechariah motifs are hardly known in rabbinic literature and medieval Jewish exegesis; with those from the Psalms (the waves, as in Ps 89:9/10: "You rule over the surging sea; when its waves mount up, you still them") and Joel (the locusts) these are quite unfamiliar appellations for the four kingdoms in Rabbinic tradition, but not in Karaite sources. Joel 1:4 is considered by this commentator as a historical allegory, but he explicitly mentions that there are two ways of reading Joel 1:4, the literal-real way and the figurative way, haqiqa ('fact') and madjaaz ('derived'). He also uses the terms zaahir ('obvious', 'outside') and mithl ('equivalent', 'similar'). Both word pairs are taken from Islamic exegesis, very popular among Karaite commentators like Yefet ben 'Eli. This text is dated in the second half of the tenth century, probably composed in Palestine or Egypt:

Daniel saw the statue of Nebuchadnesar, and he defined Babel and Chaldea to be the golden head, the breast and arms of silver to be Persia and Media, Greece and Macedonia were compared to the intestines and the hips of brass, and the iron 
thighs to be the kingdom of Edom, and he described the mixture of Edom and Ishmael in the iron and clay in feet and toes ... Then Daniel saw the four empires as beasts ... lion ... bear and panther ... and the fourth beast was not explicitly mentioned ... In addition, Zechariah compared the four empires with horses: white, black, red, and grey. In this chapter he mentions them by the typology of different locusts, all eating what others have left behind, by which he intends to say that the kingdoms did not cease to rule over the people [of Israel] and handed [it] over from one to another, but they will endure the sufferings and enslavement, as Ps 42:8 says: Deep calls to deep in the roar of your waterfalls. The enemy can be compared to a locust, and such a comparison has two aspects: their multitude; the damage they cause ... evil kings can be compared to evil animals ... Sanherib and his company were compared to flies ... On the basis of this principle, when the prophet mentions these four types of locusts, he refers to the four empires, those which Daniel has seen as beasts, and Zechariah as horses, here as locusts, informing [us] about the lasting presence of these four [empires] in [the history of] Israel

These views were supported by the Karaite Bible commentator Daniel alQumisi: no real locusts are discussed here but references to the powers of the world and metaphors for enemies. The Karaite scholar Salmon ben Yeruham in his commentary on Psalm 42:7-8 refers to the situation of Israel in exile. The succession of kingdoms was a strong and important motif for these Karaite exegetes in relation to their own acute messianism and interest in swift redemption, materialised in the Palestino-centric orientation of several subgroups such as the so-called 'mourners of Zion'. The 'mourners of Zion' launched a campaign for immigration to Palestine and appealed to their Karaite brethren to settle in Jerusalem in order to lament the destruction of the Temple and to pray for the redemption of Zion. ${ }^{27}$

\section{Conclusion}

In concluding our investigation of the use and development of the motif of the four kingdoms in liturgical poetry and prayer, it becomes clear that the Danielic scheme was an outstanding model for the development of this motif in liturgical hymnography but not in regular prayer. The hymnic-exegetical usage of the motif is subject to what has been coined by Klaus Koch as fortlaufende Aktualisierung. ${ }^{28}$ The theme is not a standard issue or a regular subject in Jewish

27 Y. Erder, "The Negation of the Exile in the Messianic Doctrine of the Karaite Mourners of Zion", Hebrew Union College Annual LXVIII, 1997, pp. 109-140; D. Frank, "The Shoshanim of Tenth-Century Jerusalem: Karaite Exegesis, Prayer and Communal Identity", The Jews of Medieval Islam: Community, Society and Identity, Leiden 1995, pp. 199-245.

28 K. Koch, Vor der Wende der Zeiten, Beiträge zur Apokalyptischen Literatur, NeukirchenVluyn: Neukirchener Verlag, 1996, p. 169. 
liturgy, but there were liturgical compositions in both classical and late eastern traditions which used the topic in its midrashic-exegetical setting. The consistency of appellations (kinuyyim) for the ruling kingdoms implies the resonance of the four empires within the context of exile and redemption. When the fifth or even eighth kingdom was understood as a new oppressor of Israel, Muslim rule was generally assigned the former Byzantine role and adapted into the scheme of the four or double four kingdoms: the conclusion was drawn by the sages and the people of Israel that the reign of Ishmael was equal to the reign of Edom. In certain turbulent times this resonance seems louder, as we have seen in the seventh century, but this also applies to a much later period, the fifteenth century, in the days before the expulsion of the Jews from Spain. A prelude to this dramatic historical event is a hymn known as geullah, usually introduced into the liturgy before the benediction Ga'al Yisra'el ("Who redeemed Israel") as a meditation on the concept of redemption. This particular composition is based on concepts adapted from the four-kingdoms motif in a tone of revenge and hope: ${ }^{29}$

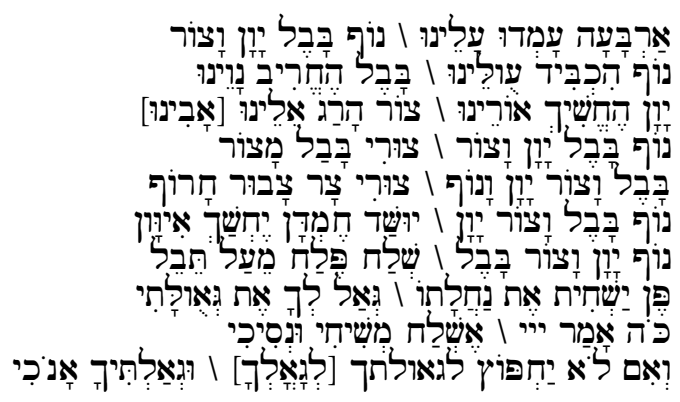

Four stood up against us: Egypt, Babylon, Greece and Tyre.

Egypt hardened our yoke, Babylon destroyed our dwelling-place,

Greece darkened our light, Tyre killed our God [our Father].

Egypt, Babylon, Greece, and Tyre: my Rock claims Babylon;

Babylon, Tyre, Greece, and Egypt: my Rock claims what has heaped up by insult;

Egypt, Babylon, Tyre, Greece: their grace will be devastated, their delight will grow dark;

Egypt, Greece, Tyre, Babylon: let [each] one be shot from the world;

lest he will crush His heritage, as you lead me to my redemption.

Thus said the Lord, I will send my anointed, my prince,

and if he is not willing to redeem you, then let Me redeem you. ${ }^{30}$

29 Manuscript Firkovicz no. 165, poem no. 244.

30 Egypt is called Noph, according to Is. 19:13: “The leaders of Noph are deceived; the cornerstones of her peoples have led Egypt astray"). The composer has chosen the name Tzor, Tyre, instead of Edom, to some extent perhaps an act of (self-)censorship. For any contemporary listener or reader there was no doubt that Tyre was a clear reference to Christian religion and rule, specifically to the power of the Catholic church in Spain. The last line is based on a quotation from Ruth 3:13. 